\title{
Modernization of Turkey under Kamal Ataturk
}

\author{
Asyraf Hj Ab Rahman ${ }^{1}$, Wan Ibrahim Wan Ahmad ${ }^{2}$, Nooraihan Ali $^{3}$, Daud Ismail ${ }^{3}$ \& Fadzli Adam ${ }^{3}$ \\ ${ }^{1}$ Centre for Fundamental and Liberal Education, Universiti Malaysia Terengganu, Malaysia \\ ${ }^{2}$ School of Social Development, Universiti Utara Malaysia, Malaysia \\ ${ }^{3}$ Faculty of Islamic Contemporary Studies, Universiti Sultan Zainal Abidin (UniSZA), Terengganu, Malaysia \\ Correspondence: Asyraf $\mathrm{Hj} \mathrm{Ab}$ Rahman, Centre for Fundamental and Liberal Education, Universiti Malaysia \\ Terengganu, Malaysia. Tel: 60-9-668-3507.E-mail: asyraf@umt.edu.my
}

Received: October 2, 2014 Accepted: December 19, 2014 Online Published: January 14, 2015

doi:10.5539/ass.v11n4p202 URL: http://dx.doi.org/10.5539/ass.v11n4p202

\begin{abstract}
Mustafa Kamal Ataturk considered one of the important figures who shape the modern life of Turkish nations. Kamal's ideology and his political structure are important to be studied since both gives important contributions towards the establishment of modern secular Turkey. This paper discusses Turkey under Kamal Atarturk. Using a secondary analysis, published materials written by scholars and writers in the field, some views and analysis of scholars like Bernard Lewis, Kemal H Karpat and several others, are reviewed and analyzed. It was found that Kemal's revolutions and reforms has brought Turkey into a new era of modernization on certain aspects but from different angels, he failed to preserve Islamic traditions and culture when he consciously amended the constitution of his country only for achieving his personal will 'Modern Turkey'. Amongst his reform were the establishment of Kamalist republic, the attack on traditional Islamic leadership, the implementation of modernist Turkified Islam and the attack on Islamic culture. These four aspects are discussed throughout this paper.
\end{abstract}

Keywords: Islam, modern Turkey, secularization

\section{Introduction}

Mustafa Kamal Ataturk (1881-1938) was regarded as the most important figure for the modernizing process of the Turkish nation. Through his nationalist ideology and modern political reforms, Kamal was able to maintain the independence of Turkey from the direct rule of the Western countries. This was done by uniting the Turkish Muslim majority and successfully led them from 1919 to 1922 in overthrowing the occupying forces out of what the Turkish National Movement considered the Turkish homeland. The Turkish identity later became the unifying force when, in 1923, the Treaty of Lausanne was signed and the newly founded Republic of Turkey was formally established. Since then, Ataturk's 15 -year rule was marked by a series of radical political and social reforms that transformed Turkey into a new era of modernization with civil and political equality for sectarian minorities and women. From another point of view, Kamal's reforms failed to preserve Islamic traditions and culture when he consciously amended the constitution of his country only for achieving his personal will 'Modern Turkey'.

The purpose of this paper is to look at Kamal's ideas and reforms for the modernization of Turkish nation during the 1920s on wards. Since the fall of the Islamic empire where Mustafa Kamal Ataturk became of the important mastermind in 1924, many procedures have been taken to minimize the religious content in both mainstream schools as well as in Islamic schools which teach Qur'an and it's sciences. All this was done under the pretext of being in line with the European ideology such as secularism and capitalism which were common in the Western world. According to Prof Bulent Daver (1988), Ataturk sought secularism as a modernizing principle due to his belief that was the only way of bringing the Turkish people becoming modern and prosperous nation.

Mustafa Kemal later known as 'Kamal Ataturk' was born in Salonica in 1881. He was the son of Ali Riza and Zubaida. During his father's death, he was about seven years old. He then was brought up by his mother with religious knowledge as she wanted him to become a good Muslim. In 1893, he entered the Military cadet. In the same year, he went on to the Military Academy in Monastir and entered the War Collage in Istanbul. In 1902, he got a promotion from the college to a teaching position on the staff. In January 1905, he graduated from the college with the rank of staff-captain (Lewis, 1968, p. 244).

From that period, his opportunity to be one of the nationalist leaders arose when at the end of the First World War, 
the Sultan of the Ottoman Empire had appointed him as Inspector-General based on Samsun, Anatolia. He was responsible to disband what remained of the Ottoman forces. Instead of disbanding the army he also created the nationalist political institutions when he gathered supporters for the war of liberation. His aim was to declare a Turkish state free from foreign control (Mansfield, 1973, p. 65). On 15 May 1917, a Greek army landed at Izmir and occupied the surrounding areas.

In fact Mustafa Kemal himself was not satisfied with the Ottoman government's policy to offer no resistance to the Greeks and other allied violations of the armistice terms. It was clear to him that the present Ottoman government seemed to oppose any nationalist ideologies that might threaten them (Lewis, 1968, p. 245). His combination with several resistance groups to defend the Turkish state against invasion was successful when the Greeks were defeated. Mustafa Kemal became a national hero in the war against the Greeks. He was given an honorific title Ghazi or 'Defender of the faith'.

\section{Method}

Data collection of this study occurs through content analysis of documents and materials mostly taken from secondary sources; published articles and books related to the subject written by scholars and writers in the field such as Bernard Lewis, Kemal H Karpat and several others. These works are reviewed and analyzed as they are, according to specific themes (Yegidis, 2002).

\section{Results and Discussions}

The following discussions are focused mainly on what has been introduced by Kamal's regime based on his new ideological orientation on Turkey and his propaganda works in achieving his goals.

\subsection{The Kemalist Republic}

Mustafa Kemal's will and his struggles for the liberation of Turkey were almost successful after the defeating of the Greeks in 1922 and the peace with the Europe at Lausanne in the same year. His achievements in both events brought to the recognition of the Istanbul government to the Kemalist groups and their political principles (Lewis, 1968 , p. 250). His next stage was the transformation of the political instrument into a real political party. This came into reality after the formation of a new party called the People's Party. The People's Party was very influential to the Turkish people and those who were sympathy to its movement. During the National Election in 1923, the People's Party took over full power. This was considered as the most successful achievement for Kemal's political career. On 29 October 1923, Turkey was proclaimed a Republic with Mustafa Kemal as President. The emergence of the Kemalist Republic marked the beginning of a new ideological orientation that was 'Modern Secular Turkey' (Kemal, 1970, p. 533). As President, Kemal's aims were to secure the independence, peace and modernization of the Turkish Republic. The modernization of Turkey however could not be achieved as long as the constitutional monarchy still in existence. Hence, his first reform was the abolition of the Sultanate and followed shortly by the abolition of the caliphate in 1924 .

The abolition of these two posts came as a shock to the Muslim world since they were the symbol of unity among the Muslims all over the world. In order to make sure that no opposition towards his actions, Kemal later declared it a capital offense to criticize whatever he did (Jameelah, 1975, p. 136). In fact, the abolition of the Sultanate and the caliphate, was a crucial step in secularization. This radical change aimed to provide the sovereignty to the Turkish nations. From Kemal's view point, the abolition of these two posts would open the new era for the administrative structure of Turkey. The Ottoman political authority must be changed for the betterment of the Turkish nations. The recent decades had seen the weakness of the Ottoman government when they were easily monopolized by the West in terms of the economic and political structure of the government. The Ottoman caliphs also seemed to be seen as the symbol of obedience of all Muslims rather than playing their role as great Muslim leaders respected by other nations. Therefore it was the time, this corrupted government be replaced with the new government and administration who would protect all Muslims and fulfill their role in accordance with the needs of modern Turkish nations.

In order to convince the people on the need of this reform, Kemal stated that the Prophet himself never mentioned to all Muslims about the need for caliphate. The Prophet only instructed his disciple to convert the nations of the world to Islam (Enayat, 2005, p. 53) Therefore, it was permissible for all Muslims to choose any type of government they like as long as the such government was able to play its role and administer all Muslim nations.

It should be noted that, the abolition of the caliphate by Kemal's groups got supports from some Muslims scholars. Abu'l-Kalam Azad, a well-known 'ulama' from India, was in agreement with Kemal's reforms. To him, the spiritual leadership is the due of God and all Prophets and not for the caliphate. Another Muslim scholar such as Iqbal, also approved of the abolition of the Caliphate since the post had no longer played its role for the betterment of all Muslims. The moral supports from these two scholars were more than enough for Kemal to continue the 
reform. It was believed that the abolition of the Sultanate and the Caliphate, had enabled Kemal to proceed to another reforms since there was no more Muslim authority who would hinder him from continuing his secular reforms In fact, Kemal's secular reforms had been planned so well and very cunning. It began from the heads of state to the lower ranks that involved all the people of Turkey.

\subsection{The Attack on Traditional Islamic Leadership}

It was clear that, Kemal's reform, which based on the Western ideology; 'the national sovereignty and the eliminating of the Islamic authority' became the direct attack on the traditional Islamic leadership. The abolition of the Sultanate and the Caliphate was later accompanied by other series of reforms. In 1923, the institutions of 'ulama' called Sheikh-al-Islam and the ministry of the Shari'a were abolished. Their numbers also declined. The abolition of these official institutions gave a great impact to the practise of religion among the Turkish people. There was no more religious institution which issued fatwa regarding religious matters.

In 1924, another series of reforms began, leading to the closing of religious school and colleges. Kemal saw the existence of these schools or 'medresa' would prevent the Turkish people from having contacts and association with the West. They would also become the obstacle to the modernization of the Turkish Republic (Nabi, 1968, p. 323). In 1925, the Sufi orders were suppressed in the country when one of its leaders, Sheikh Said (Note 1) was sentenced to death. The Kemalist regime saw the existence of such dervish orders and any other Sufi whirling, was something to make people to become ecstatic fools and uncivilized (Kedourie, 1992, p. 104). It should be noted that the suppression of the sufi orders by the Kemalist regime, had been seen by a great part of the population as something acceptable and not against Sufism. Most of the people saw the suppression aimed to combat against the corrupt pretenders to Sufism who made such public display of their piety. Moreover, Kemal's reforms from their eyes, aimed to purify Islam from un-Islamic practices. This was one of the factors contributed to the success of Kemal's reforms in eliminating the Islamic leadership in Turkish society. As the result of the suppression, there was no more public activities of the tariqah orders. Many khanagahs which at once, became centre for Sufis teachings, were turned into museums.

In 1926, the Islamic Law (Sharia') was replaced by the Swiss Civil code of Law. This law forbade polygamy and gave wives authority to seek divorce. The adaptation of the Western style of Law into the Turkish Republic seemed to give no room for the Islamic Personal Law concerning the marriage, divorce and inheritance. In 1928 there was another amendment in the Turkish Constitution that to remove the article which stated Islam as the official religion of the state. By introducing the Western Law, the Kemalist regime tried as much as they could, to expose the people with the Western civilization regarding the legal and large-scale institutional structures. However it is quite interesting to see that Kemal, despite of his eagerness in implementing the Western law on Muslim personal status, he still showed his loyalty to the Muslim community when he would not let a Muslim women be married to non-Muslims.

\subsection{The implementation of Modernist Turkified Islam}

The abolition of the traditional Islamic leadership that caused the rebellions and oppositions against Kemalist Republic made no sense for Kemal. Through the 'law for the maintenance of order ' he used to execute any oppositions and rebellions in the country. A move to implement the Modernist Turkified Islam, was another reform towards the modernization of the Turkish Republic. Since the sovereignty belongs to the Turkish nation, therefore the religion of Islam has to be reformed and reinterpreted in accordance to the Turkish national identity and needs. In 1928, the regime had introduced a Latin-based alphabet to replace the Arabic letters. (Mansfield, 1973, p. 67) In 1933, the Arabic call to prayer had also been substituted with the Turkish language. A further step to get rid the influence of Arabic language in the Quran was taken when there was a project to translate the Quran into Turkish language. This project was regarded as one of the most controversial acts of secularization within the Kemalist Republic. Since the Divine revelation was in Arabic language, therefore the Arabic translation of the Quran according to Kemal, would be a tampering with the word of God. In 1932 the translation of the Quran in Turkish language had been read publicly. Those reforms in many respects, aimed to decrease the influence of Arabic and Islamic civilization within the Turkish society. They gave a big impact for Turkish society in general and their new generations in particular. The reforms also cut the young generation off from access to the rich heritage of Ottoman literature that was preserved mostly in Arabic scripts (Cleveland, 1986, p. 170). They also got difficulty to understand and assimilate the religious books written in Arabic. Yasar Nabi Nayar has cited in his article concerning this matter when he said that: "Today, the new generations find it easy to understand the West in various branches of science and fine arts and equally difficult to understand and assimilate the East. This difference opened a gap in understanding between the new and old generation" (Nayir, 1968, p. 23). As a result of this reform, the students enrollment into the faculty of Theology at the University of Istanbul was also decreased. The faculty later was consolidated in 1933 with the department of literature. 


\subsection{The attack on Islamic culture}

Since Islam had blocked the progress of Turkey, therefore its authority should be eliminated and abolished totally. The elimination of the authority of Islam includes all social and political power of the Islamic religious authorities (Mansfield, 1973, p. 67). There were several steps taken by Kemalist regime to eradicate this harmful legacy of Islam such as the banning of the fez and turban then replaced it with the Western-style hats and caps. Mustafa Kemal regarded the fez and turban as a symbol of the unenlightened traditionalism that kept Turkey backward. (Mansfield, 1973, p. 67).

In 1925 the Islamic time and calendar systems was replaced by European ones. As a result of this, Sunday was recognized as a legal holiday for Turkey. In 1926 another law was enacted by which making legal the consumption of alcohol by Muslims. This followed by the emancipation of woman in 1925-1935. This was considered as a drastic change for the women's status when it protected the freedom of women in the society. They began to have equal right with men regarding divorce, ownership of property, custody of children, etc. Women also began to have equal legal treatment; from no political representative and participation to full suffrage. Another critical attack to the Islamic culture was the banning of religious dress. It was forbidden to wear religious dress outside places of worship. In fact the law concerning the dress code was enacted since there was the misuse of the religious dress for the purpose of achieving authority over the ignorant people (Yasar, 1968, p. 323). These cultural modernization imposed by the Kemalist regime reached its conclusion with the adoption of Western surname in 1934. Mustafa Kemal chose for himself 'Ataturk' that means 'the father of the Turk'. Through the cultural reformation, Kemal hoped that Islam and its heritage would be destroyed and thus Turkey was thoroughly modernized socially and culturally.

\section{Concluding Remarks}

Turkey was regarded as the first Muslims country that declared as a secular state. Mustafa Kemal Ataturk who is recalled as the father of the nation was responsible for the establishment of modern Turkey. His revolutions and reforms have brought Turkey into a new phase of development. In doing so, he amended the constitution of his country besides abolishing position of the Sultanate and the caliphate that ever since regarded as a symbol of unity among Muslims all over the world. Despite many cultural barriers, his revolutions and reforms have brought Turkey into a new era of modernization even though he consciously realized that such reforms will destroy every vestige of Islam in the life of the Turkish nation. The consequences of Ataturk's reforms are still being felt today throughout the Muslim world, and especially in a very polarized and ideologically segmented Turkey.

\section{References}

Cleveland, W. L. (1986). A History of the Modern Middle East. Colorado: West View Press.

Daver, B. (1988). Secularism in Turkey. Atatürk Araştırma Merkezi Dergisi (pp. 297-309).

Enayat, H. (2005). Modern Islamic Political Thought. London: I.B Tauris \& Co Ltd.

Fisher, S. N. (1959). The Middle East: A History. London: Routledge \& Kegan Paul Ltd.

Jameelah, M. (1975). Islam and Modernism. Lahore: Kazi Publication.

Karpat, K. H. (1970). Modern Turkey. In P. M. Holt, \& K. S. A. Lambton (Eds.), The Cambridge History of Islam (Vol. 1). London: Cambridge University Press.

Kedourie, E. (1992). Politics in the Middle East. Oxford University Press.

Lewis, B. (1968). The Emergence of Modern Turkey. Oxford: Oxford University Press.

Mansfield, P. (1973). The Ottoman Empire and its Successors. New York: St. Martin's Press.

Nayir, Y. N. (1968). Ataturkism Is Secularism. In K. H. Karpat (Ed.), Politics and Social Thought in the Contemporary Middle East. London: Pall Mall Publication.

Yapp, M. E. (1991). The Near East Since The First World War. London: Longman.

Yegidis, B. L., \& Weinbach, R. W. (2002). Research Methods for Social Workers. Boston: Allyn and Bacon.

\section{Note}

Note 1. He was the leader of Naqshabandi Tariqah or Sufi order.

\section{Copyrights}

Copyright for this article is retained by the author(s), with first publication rights granted to the journal.

This is an open-access article distributed under the terms and conditions of the Creative Commons Attribution license (http://creativecommons.org/licenses/by/3.0/). 